\title{
ASSOCIATIONS OF ORE MINERALS IN THE DEPOSITS OF THE SEINÄJOKI DISTRICT AND THE DISCUSSION ON THE ORE FORMATION
}

\author{
YU. S. BORODAEV; N. S. BORTNIKOV; N. N. MOZGOVA; N. A. OZEROVA; P. OIVANEN \\ and V. YLETYINEN
}

\begin{abstract}
BORODAEV, YU. S.; BORTNIKOV, N. S.; MOZGOVA, N. N.; OZE: ROVA, N. A.; P. OIVANEN and V. YLETYINEN, 1983: Associations of ore minerals in the deposits of the Seinäjoki district and the discussion on the ore formation. Bull. Geol. Soc. Finland 55, 1, 3-23.

The mineral associations of the antimony deposits in the Seinäjoki region (Finland) are described on the basis of microprobe investigations. There are two ore associations: quartz-antimony and pyrrhotite-antimony. The latter is characterized by the presence of the new minerals seinäjokite and pääkkönenite first discovered in these deposits. The data obtained suggest that minerals were formed in the deposits under specific conditions: at relatively high temperatures for antimony deposition, and at extremely low sulphur fugacity for the hydrothermal process.
\end{abstract}

Key words: Antimony, seinäjokite, pääkkönenite, sulphur fugacity Seinäjoki.

Yu. S. Borodaev, N. S. Bortnikov, N. N. Mozgova and N. A. Ozerova: IGEM, Staromonetnyi 35, Moscow 109017, USSR.

P. Oivanen and V. Yletyinen: Geological Survey of Finland, SF-02150 Espoo 15, Finland.

\section{Introduction}

The Seinäjoki ore district, situated in western central Finland, is unique for its deposits of native antimony. The content of native antimony amounts to $80-90$ per cent in some of the occurrences. For some years the Seinäjoki district has been subjected to geological, geophysical and explorational investigations conducted by the Geological Survey of Finland. The work was headed by V. Pääkkönen, who was the first to study thoroughly the geology of the deposits, to describe the antimo- ny ores in detail and to advance some suggestions on their genesis (Pääkkönen 1966). During the last few years exploration has concentrated primarily on two deposits, Kalliosalo and Tervasmäki.

The results presented here are based on a study of the ore samples collected by N. N. Mozgova and N. A. Ozerova from the deposits of Syrjämö, Routakallio, Tervasmäki, Kalliosalo and Sikakangas during an excursion organized by the Geological Survey of Finland in the Seinäjoki ore district in 1978, on samples collected by P. Oivanen and V. Yletyi- 
nen, and on minerals kindly placed at our disposal by the late V. Pääkkönen. The ores were investigated at the Geological Faculty of the Moscow State University and at the Institute of Geology of Ore Deposits, Petrography, Mineralogy and Geochemistry (IGEM) of the USSR Academy of Sciences. The unique antimony ores from Seinäjoki were studied employing electron microprobe analysis. This allowed us to add considerably to V. Pääkkönen's data on the chemical composition of ore minerals, to reveal some specific features of paragenetic correlations, to discover some minerals previously unknown in this ore district and to find some mineral species which had not been found anywhere in nature before. Our knowledge of the specific features of the geochemistry and mineralogy and of the conditions of formation of the natural antimony deposits of the Seinäjoki district has been thereby greatly enhanced. Detailed investigations of native metals and intermetallic compounds have been carried out recently on the deposits in which the inclusions of these minerals occur as separate grains of very small and even microscopic size (Karup-Møller 1978; Novgorodova 1980 et al.). The Seinäjoki deposits are a fortunate exception in this respect as the grains of native antimony are fairly large, and a number of minerals are associated intimately with the antimony.

\section{Geological position of the Seinäjoki ore district}

The Seinäjoki ore district lies at the boundary of the Central Finland granitoid area within the schist zone of metamorphic rocks of Middle Proterozoic age. The metamorphic rocks are represented by biotite gneisses, migmatites, mica schists, quartzites and volcanic rocks of intermediate and acid composition.
The intrusive magmatic rocks found in the district constitute younger complex of synorogenic granitoid rocks: quartz diorites, granodiorites, granites and the pegmatites associated with them. The rocks were formed during the main phase of metamorphism and deformations that occurred 1800-1900 million years ago (Simonen 1980). The antimony mineralization took place during the second phase of metamorphism associated with orogenesis (Pääkkönen 1966).

The Seinäjoki ore district is an anticlinal structure about $20 \mathrm{~km}$ wide. It consists of a series of isoclinal folds with a steep northeastern plunge. The folded structure is complicated by faults of several systems in which faults striking north west predominate. The ore zone, which is about $8 \mathrm{~km}$ long and at least $1 \mathrm{~km}$ wide, is located within the faults. It includes nine deposits, and a tenth one is situated somewhat to the south-west of the zone (Fig. 1).

Various rocks of the schist series are mineralized: quartz-sericitic and graphite schists, mica gneisses, acid igneous rocks and porphyrites, often along the contact of volcanic rocks differing in composition. The majority of the mineralizations are in veins and stockworks, where the ore minerals form nests, veinlets and impregnations.

The ores of the Seinäjoki deposits are characterized by a relatively complex mineral composition (Table 1). Note that the mineral compositions are of almost the same type in all the deposits.

The principal ore minerals are native antimony, pyrrhotite and arsenopyrite. The ores contain appreciable amounts of gudmundite, antimonite, berthierite, löllingite and marcasite. Other minerals occur in insignificant amounts. The group of rare minerals found for the first time in the ores of the Seinäjoki district is of particular interest. They include the recently discovered mineral species, seinäjokite and pääkkönenite, and compounds 

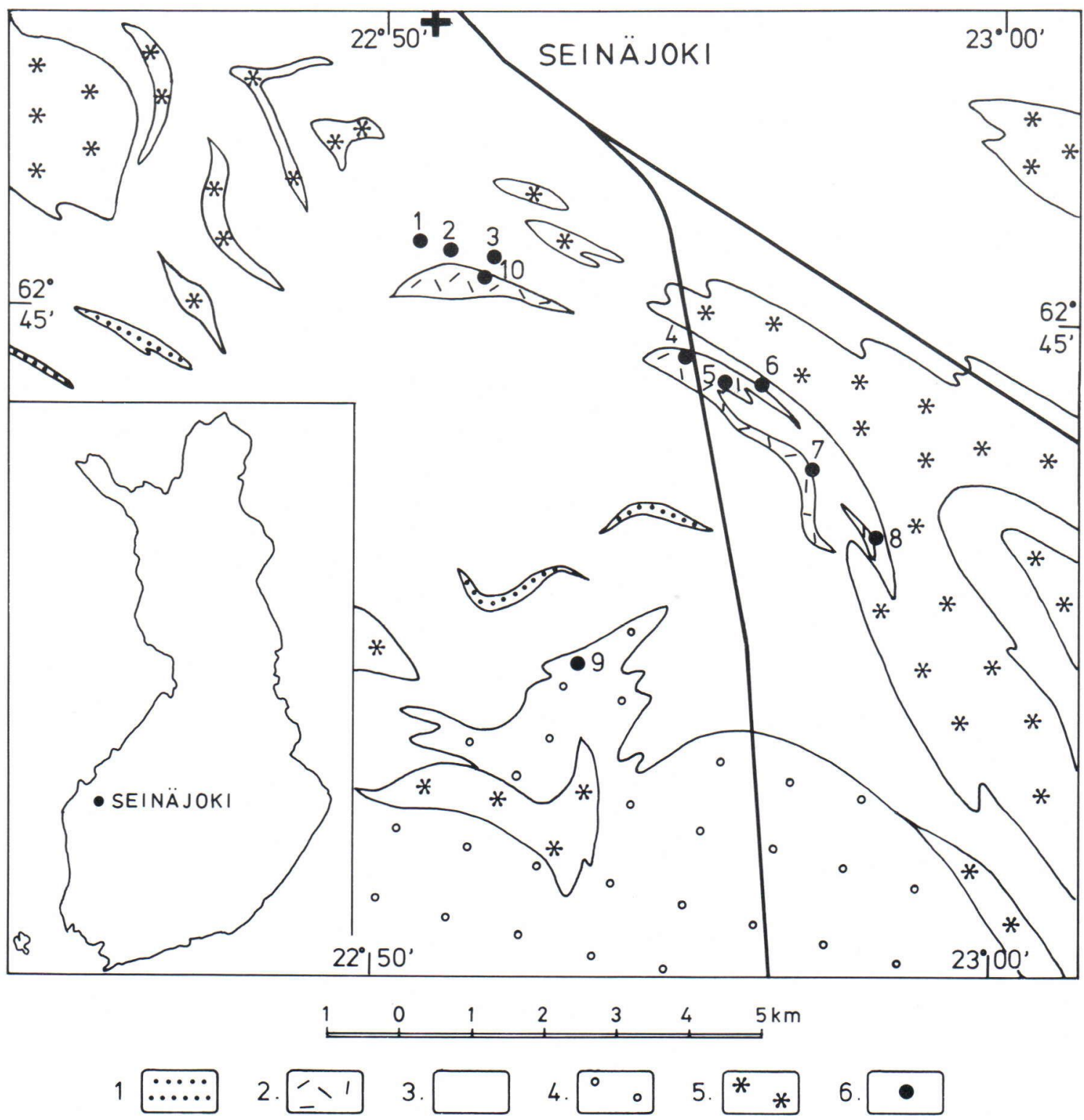

Fig. 1. Scheme of geological structure of the Seinäjoki ore district.

1. Amphibolite and hornblende gneiss, 2. Plagioclase porphyrite, 3. Mica schist and mica gneiss, 4. Quartz diorite and granodiorite, 5. Pegmatite and pegmatite granite, 6. Antimony deposits (1- and 2-Törnävä, 3-Syrjämö, 4-Routakallio, 5-Lootakallio, 6-Tervasmäki, 7-Kalliosalo, 8-Marttalanniemi, 9Sikakangas, 10-Satamo). 
Table 1. Distribution of ore minerals in the deposits of the Seinäjoki ore district.

\begin{tabular}{|c|c|c|c|c|c|c|c|}
\hline & $\begin{array}{l}\text { Deposits } \\
\text { Minerals }\end{array}$ & Törnävä & Syrjämö & Routakallio & Tervasmäki & Kalliosalo & Sikakangas \\
\hline \multirow{8}{*}{$\sum_{\Sigma}^{\pi}$} & Antimony, native & $\oplus$ & $\oplus$ & + & + & + & + \\
\hline & Pyrrhotite & $\oplus$ & $\oplus$ & + & + & + & + \\
\hline & Arsenopyrite & $\oplus$ & $\oplus$ & + & + & + & + \\
\hline & Stibnite & $\oplus$ & $\oplus$ & + & + & + & + \\
\hline & Gudmundite & $\oplus$ & $\oplus$ & + & + & + & + \\
\hline & Berthierite & 0 & 0 & + & + & + & + \\
\hline & Löllingite & 0 & 0 & + & + & + & + \\
\hline & Marcasite & 0 & $\oplus$ & + & + & + & + \\
\hline \multirow{4}{*}{ 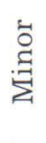 } & Sphalerite & 0 & 0 & + & + & + & + \\
\hline & Chalcopyrite & 0 & 0 & + & + & + & + \\
\hline & Fahlore & & 0 & + & & + & \\
\hline & Sb-arsenopyrite & & & & & + & \\
\hline \multirow{15}{*}{ 䒕 } & Pyrite & 0 & 0 & & & + & \\
\hline & Pääkkönenite & & & & & + & \\
\hline & Y-mineral & & & & & + & \\
\hline & Z-mineral & & & & & + & \\
\hline & Zinkenite & & & & & + & \\
\hline & Jamesonite & 0 & & & & & \\
\hline & Seinäjokite & & & + & & & \\
\hline & Sb-westerveldite & & & + & & & \\
\hline & Stibarsen & & & + & & & \\
\hline & Breithauptite & 0 & & & & & \\
\hline & Aurostibite & & & + & & & \\
\hline & Altaite & & & + & & & \\
\hline & Gold, native & 0 & 0 & & & & \\
\hline & Hematite & 0 & 0 & & & & \\
\hline & Scheelite & 0 & 0 & & & & \\
\hline
\end{tabular}

Note: $\bigcirc$ - from data by V. Pääkkönen;

$\oplus$ - from data by the authors and V. Pääkkönen (1966);

+ - from data by the authors.

previously unknown in nature, which in this context have been designated "mineral $\mathrm{Y}$ » and »mineral $\mathrm{Z} »$.

The main types of wall-rock alteration are silicification and sericitization. In some cases the ore mineralization has been traced to a depth of up to $100 \mathrm{~m}$ (the Kalliosalo deposit).

\section{Associations of ore minerals}

A study of the ores of the Seinäjoki deposits reveals that the two main ore minerals, native antimony and pyrrhotite, are not nor- mally intergrown. Wherever one of the two is predominant, the other is either absent or in subordinate amounts; they are never in contact with each other. Within the ore zones the native antimony is concentrated in quartz veins and in intensely silicified rocks. A number of other ore minerals are associated with both the native antimony and the pyrrhotite but in widely varying proportions. Two main mineral associations, quartz-antimony and antimony-sulphide, can thus be established in the ore district (Table 2). The first association is characterized by a pronounced subordinate occurrence of other antimony and 
Table 2. Distribution of minerals according by association.

\begin{tabular}{llll}
\hline Associations & Main minerals & Minor minerals & Rare minerals \\
\hline Quartz-antimony & Native antimony & Stibnite & Seinäjokite \\
& Quartz & Pyrrhotite & Sb-westerveldite \\
& Arsenopyrite & Pääkkönenite & Altaite \\
& Lölingite & Sb-arsenopyrite & Stibarsen \\
& & Berthierite & Y-and Z-minerals \\
& & Gudmundite & Zinkenite \\
\hline Antimony-sulphide & Pyrrhotite & Löllingite & Pyrite \\
& Gudmundite & Sphalerite & Chalcostibite \\
& Berthierite & Chalcopyrite & Breithauptite \\
& Stibnite & Fahlore & \\
& Arsenopyrite & Native antimony & \\
& Marcasite & Quartz & \\
\end{tabular}

antimony-bearing minerals (stibnite, berthierite and others). The second association contains comparatively large amounts of sulphides of antimony such as gudmundite, berthierite and stibnite. It was only in the quartz-antimony association, however, that the group of very rare minerals specific to the Seinäjoki ore district (seinäjokite, Sb-westerveldite, pääkkönenite and others) was found.

\section{The quartz-antimony association}

The principal ore mineral of this association, native antimony, occurs as irregular grains and nests in the intersticies between quartz grains and as short veinlets in quartz. The antimony may occasionally distinctly replace the quartz.

Native antimony normally contains small idiomorphic inclusions of arsenopyrite and löllingite and other more rare minerals. Idiomorphism of arsenic minerals grains, and the presence of antimony veinlets carring the crystals of arsenopyrite and löllingite suggest that these minerals were formed earlier than the native antimony (Pääkkönen 1966). However, because they are regularly arranged in the peripheral parts of the host mineral, some of the crystals of arsenopyrite and lollingite associated with native antimony are younger and are of metasomatic origin (Fig. 2). As shown by the formation of arsenopyrite rims around it (Fig. 3). Rare minerals such as pääkkönenite, seinäjokite, Sb-westerveldite, altaite and others were formed almost simultaneously with native antimony or developed metasomatically, as is revealed, for example, by the antimony relicts in idiomorphic crystals of Sb-westerveldite (Mozgova et al. 1976 and 1977). The youngest ore mineral of this

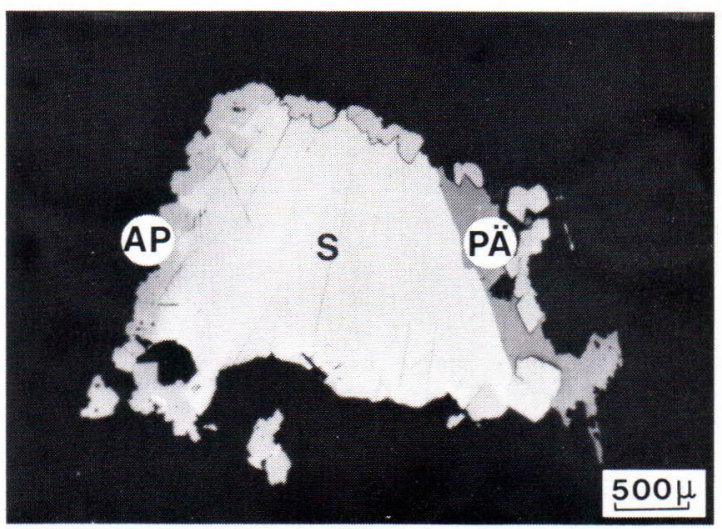

Fig. 2. Native antimony (S) intergrown with pääkkönenite (PÄ) and arsenopyrite (AP) in quartz (black). 


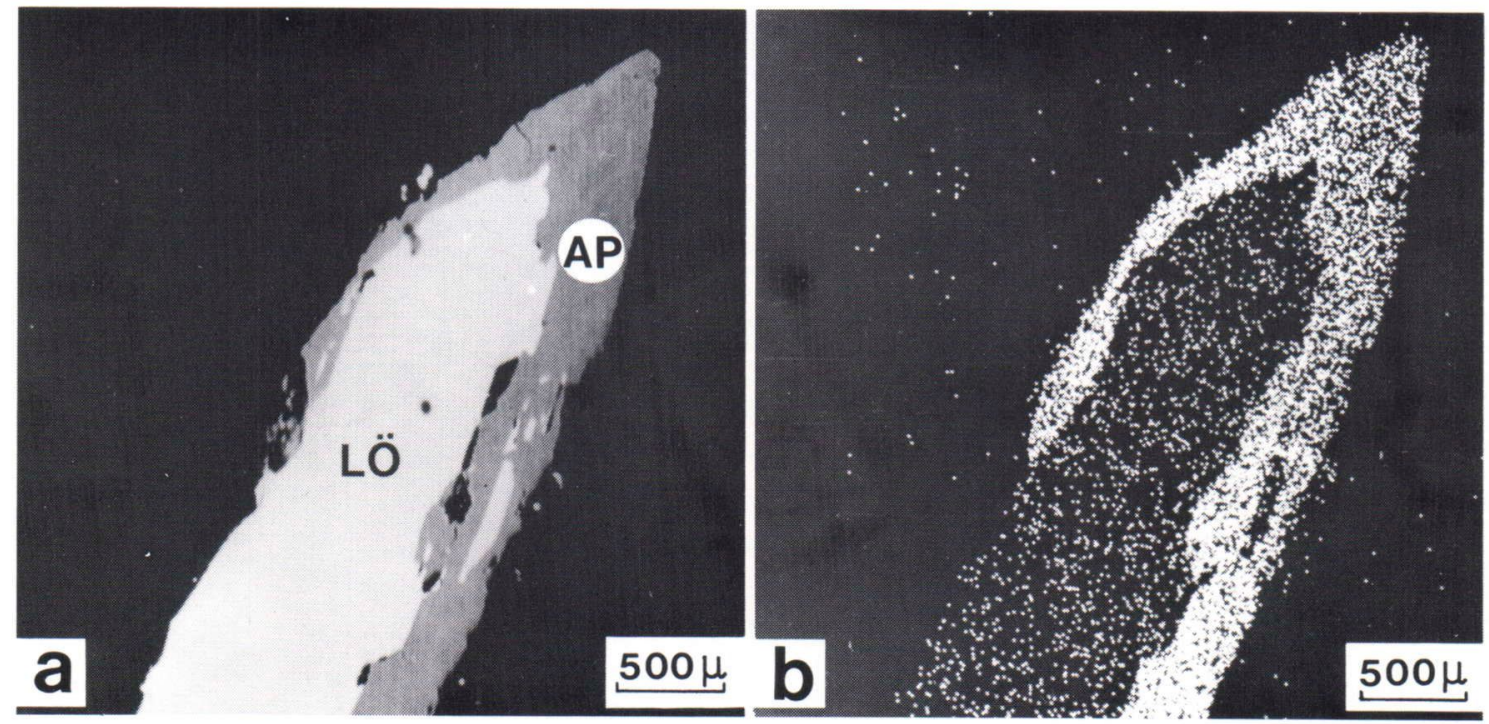

Fig. 3. Crystal of löllingite (LÖ) replaced by arsenopyrite (AP) along the boundaries. a) backscattered electron image; b) $\mathrm{SK} \alpha_{1} \mathrm{X}$-ray image.

association is stibnite, which forms rims around and occurs as veinlets cutting the grains of native antimony.

\section{Pyrrhotite-antimony association}

The principal mineral of this association is pyrrhotite, which also occurs on a regional scale. According to Pääkkönen (1966), this mineral is normally found, albeit in small amounts, in mica gneiss. In some places it is so abundant that it causes magnetic anomalies. In accordance with Lepp (1957), Pääkkönen (1966) was of the opinion that metamorphism produces iron sulphides from melnikovite and other black unstable compounds of ferrous sulphide known to accumulate on the floor of sea basins and lakes together with organic material subjected later to graphitization. Some chalcopyrite, sphalerite and hematite seem to be of similar origin.

In the ore zones of the Seinäjoki deposits the pyrrhotite seems to be of an older generation, and in some places the pyrrhotite im- pregnations are quite large. This is probably due to the accumulative recrystallization of primary pyrrhotite under the influence of hydrothermal solutions. Pyrrhotite was partially redeposited, thereby cementing the fragments of metamorphic rocks in the zones of brecciation (Fig. 4).

Pyrrhotite is often replaced by marcasite. Pyrrhotite grains are frequently surrounded by gudmundite rims (Figs. 4 and 5 ) that in some places exhibit submicroscopic and coarse graphic textures of gudmundite and pyrrhotite intergrowth (Fig. 6). Pääkkönen (1966) believed that the development of gudmundite was due to the reaction of pyrrhotite and native antimony:

\section{$\mathrm{FeS}+\mathrm{Sb}->\mathrm{FeSbS}$.}

The reactional origin of the gudmundite rims around pyrrhotite is confirmed by the presence of small pyrrhotite inclusions whose optic orientation is the same as that of the main pyrrhotite grain.

The pyrrhotite and the gudmundite rims are replaced by berthierite, which sometimes contains non-replaced relicts of these miner- 


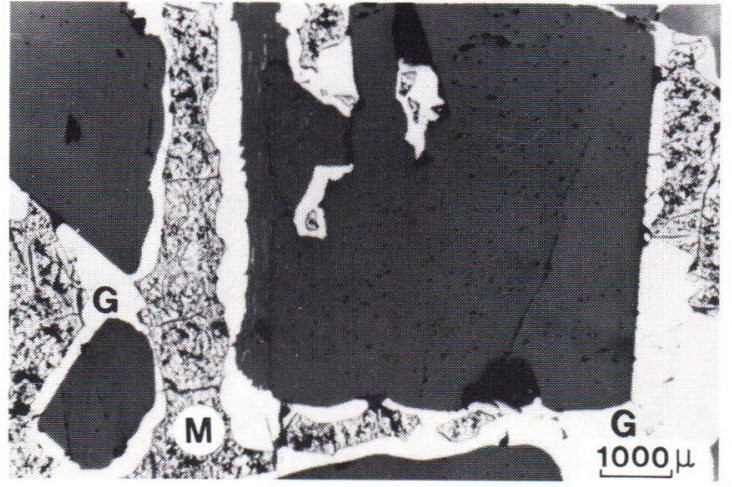

Fig. 4. Fragments of the enclosing metamorphic rock cemented by gudmundite $(G)$ and marcasite (M), which replaces pyrrhotite.

als and their graphic intergrowths (Fig. 7). The three minerals are in turn replaced by stibnite that forms reaction rims around their grains and cutting veinlets inside them. It has been observed that stibnite veinlets in pyrrhotite crosscut chalcopyrite veinlets formed earlier. Stibnite is most intensely developed after pyrrhotite and is partially replaced by laminar marcasite. Complete stibnite-marcasite pseudomorphs after pyrrhotite are often encountered (Fig. 8). The relationships between pyrrhotite and antimony minerals demonstrates that the latter resulted from the

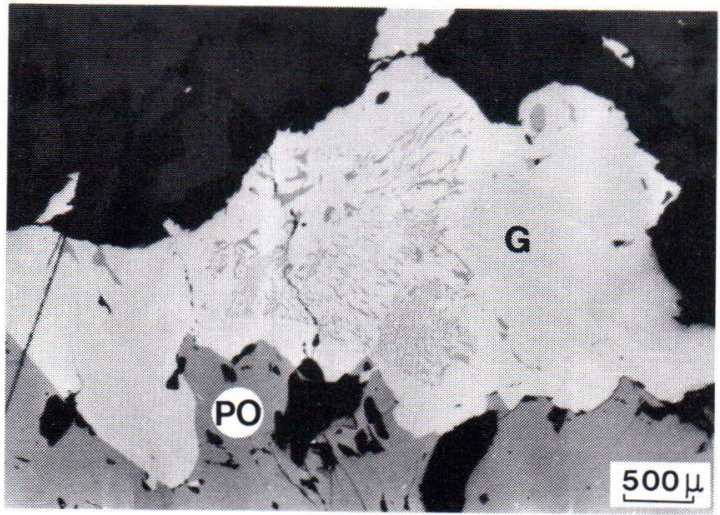

Fig. 6. Micrographic texture of pyrrhotite in gudmundite $(\mathrm{G})$ close to the contact with pyrrhotite (PO).

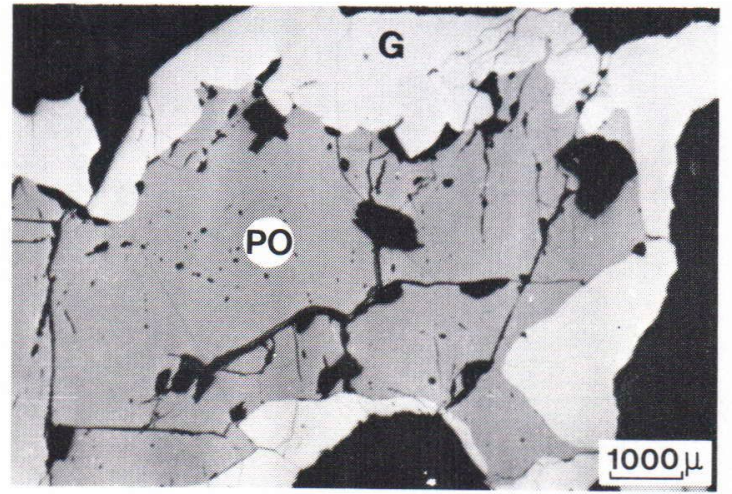

Fig. 5. Pyrrhotite (PO) surrounded by gudmundite $\operatorname{rim}(G)$.

reaction between antimony-bearing solutions and pyrrhotite.

Contact relationships between pyrrhotite and native antimony - the main minerals of the various associations - have not been observed. In the comparatively rare cases when the two minerals are found in the same ore aggregate, gudmundite and berthierite occur between them: The absence of crosscutting relationships suggests that, as pointed out earlier by Pääkkönen (1966), the two associations were formed from the same solution but in different physical and chemical environ-

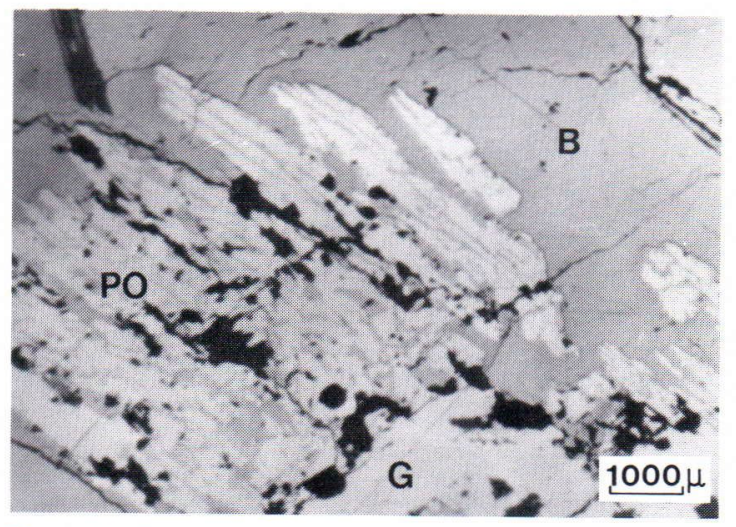

Fig. 7. Intergrowth of gudmundite (G) and pyrrhotite (PO) in berthierite (B). 


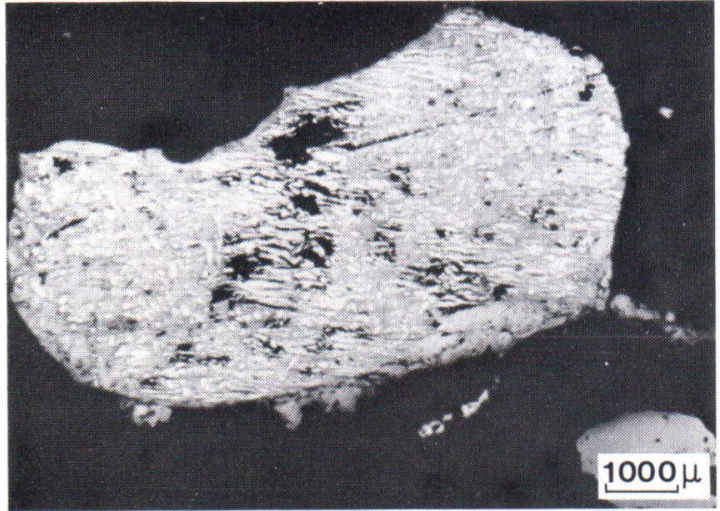

Fig. 8. Complete replacement of pyrrhotite by marcasite and stibnite.

ments. The rock were probably subjected to the most intense reworking in the sections of quartz-antimony mineral association, which resulted in the complete removal of pyrrhotite. Antimony-sulphide association was formed in the enclosing rocks, which were less intensely altered. The order of crystallization of the main ore minerals is shown by the following idealized scheme:

Quartz-antimony association:

löllingite $\longrightarrow$ arsenopyrite $\longrightarrow$ native antimony

Antimony-sulphide association:

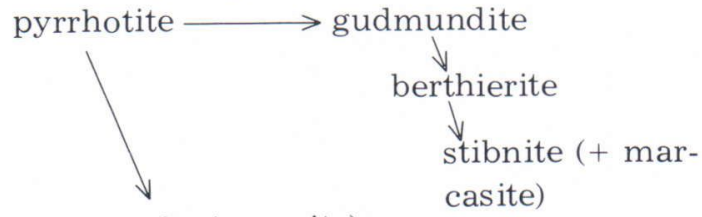

marcasite (+ pyrite)

\section{Ore minerals of the Seinäjoki Deposits}

The present section deals with specific features of the chemical composition of the minerals, which were studied using the microprobe JXA-5 at the Laboratory of Ore Microscopy of the Geological Faculty of Mos-

cow State University. The conditions of the microprobe analyses were as follows: accelerating voltage $25 \mathrm{kV}$, sample current $0.5-$ $2.0 \cdot 10-{ }^{8} \mathrm{~A}, \mathrm{X}$-ray take-off angle $40^{\circ}$, probe diameter $\sim 1 \mu$. Analytical $\mathrm{K} \alpha_{1}$ lines were employed for $\mathrm{S}, \mathrm{Fe}, \mathrm{Co}, \mathrm{Ni}, \mathrm{Cu}, \mathrm{Zn} ; \mathrm{L}_{1}$ for $\mathrm{Sb}$ and $\mathrm{Te}$; and $\mathrm{M} \alpha$ for $\mathrm{Au}$ and $\mathrm{Pb}$. As was measured on $\mathrm{K} \alpha_{1}$ or $\mathrm{L} \alpha_{1}$, depending on the composition of the mineral phase. Pure metals ( $\mathrm{Fe}, \mathrm{Co}, \mathrm{Ni}$, $\mathrm{Cu}, \mathrm{Zn})$, minerals - galena $(\mathrm{PbS})$, chalcostibite $\left(\mathrm{CuSbS}_{2}\right)$, arsenopyrite (FeAsS), stibnite $\left(\mathrm{Sb}_{2} \mathrm{~S}_{3}\right)$ and artificial compounds ( $\mathrm{FeS}$ and GaAs) were used as standards. Corrections were done according to a computer program modified from one by Springer (1967).

\section{Pyrrhotite $\left(\mathrm{Fe}_{1-\mathrm{x}} \mathrm{S}\right)$}

Pyrrhotite occurs as a fine-grained (up to $2 \mathrm{~mm}$ ) impregnation that normally extends along the schistosity. The grain size of this mineral occasionally reaches $0.5 \mathrm{~cm}$. As was first established by Pääkkönen (1966) using the X-ray method, both monoclinic and hexagonal pyrrhotite modifications are present in the ores. The presence of the two modifications corroborated by applying magnetic suspension. The microprobe analyses revealed that the composition of the magnetic monoclinic pyrrhotite was $\mathrm{Fe}_{0,86-0,87} \mathrm{~S}$ and that of the nonmagnetic hexagonal pyrrhotite $\mathrm{Fe}_{0.87-0,92} \mathrm{~S}$. The pyrrhotite exhibits great compositional variations, even within a single grain (from $\mathrm{Fe}_{0.86} \mathrm{~S}$ to $\mathrm{Fe}_{0,92} \mathrm{~S}$ ). Alternating zones of magnetic and non-magnetic modifications of pyrrhotite were often observed. None of the pyrrhotite grains analysed contained $\mathrm{Ni}$.

\section{Marcasite $\left(\mathrm{FeS}_{2}\right)$}

This mineral often replaces pyrrhotite within the mineralized zones. Three types of replacement can be observed: 1. partial or complete replacement by laminar marcasite crys- 


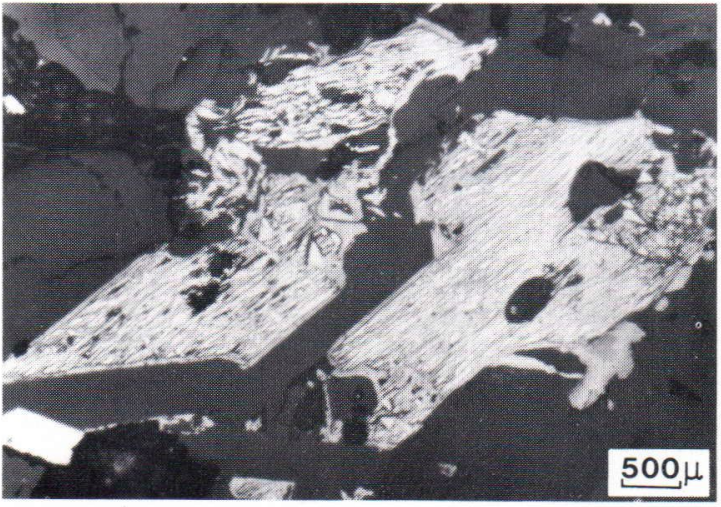

Fig. 9. Replacement of pyrrhotite by laminar marcasite. Stibnite rims can be observed at the boundaries of the grains.

tals (Figs. 9, 8 and 4); 2. formation of loopshaped and ring-shaped replacement textures. The marcasite rings frame the fresh pyrrhotite nuclei concentrically (Fig. 10) or are developed within it to form lenses and oval inclusions (Fig. 11); 3. development of a cellular substitution texture. In this texture the pyrrhotite grain is broken into individual blocks separated by septa of microcrystalline and distinctly anisotropic marcasite, marcasite itself being partially or completely replaced by a fine-grained anisotropic substance described by Ramdohr (1975) as an

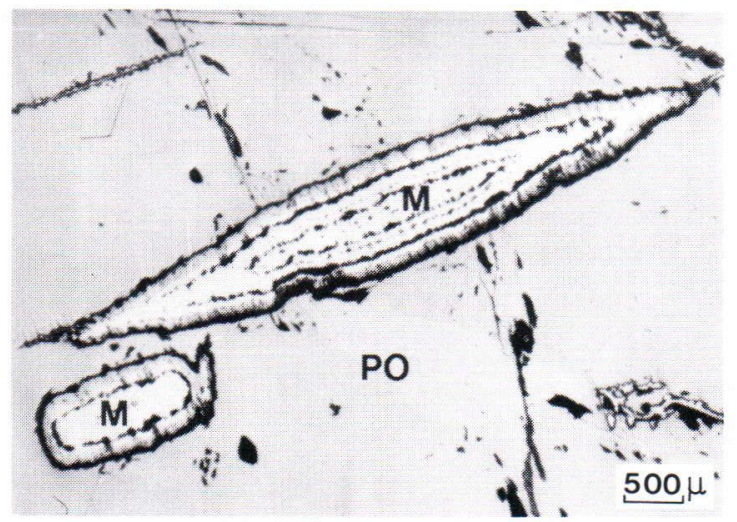

Fig. 11. Ring-shaped marcasite (M) aggregates in pyrrhotite (PO).

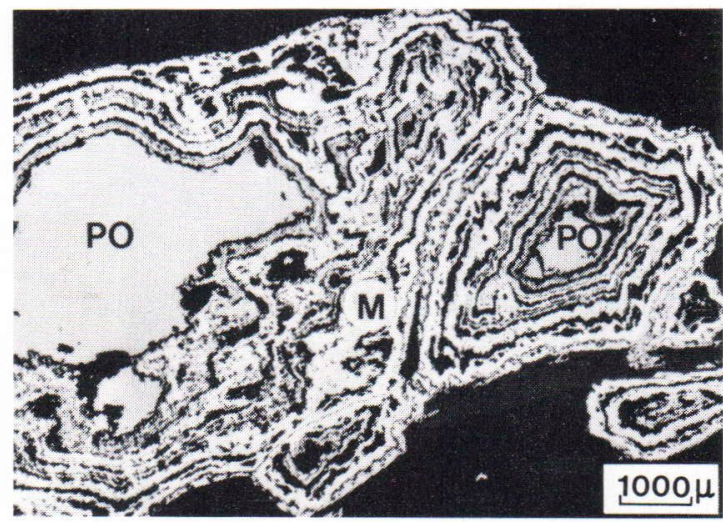

Fig. 10. Loop-and-ring replacement texture of pyrrhotite (PO) by marcasite (M).

"intermediate product» (Fig. 12). Microprobe analyses of the latter revealed that it was close to the stoichiometric $\mathrm{FeS}_{2}$ in composition but that it was characterized by the presence of antimony (from 0.9 to $3.5 \%$ ). Antimony is also present in the marcasite of septa in approximately the same amounts.

\section{Native antimony $(\mathrm{Sb})$}

Native antimony normally occurs as a finegrained impregnation. The grains are irregular in shape and up to $2-3 \mathrm{~mm}$ in size. Rare

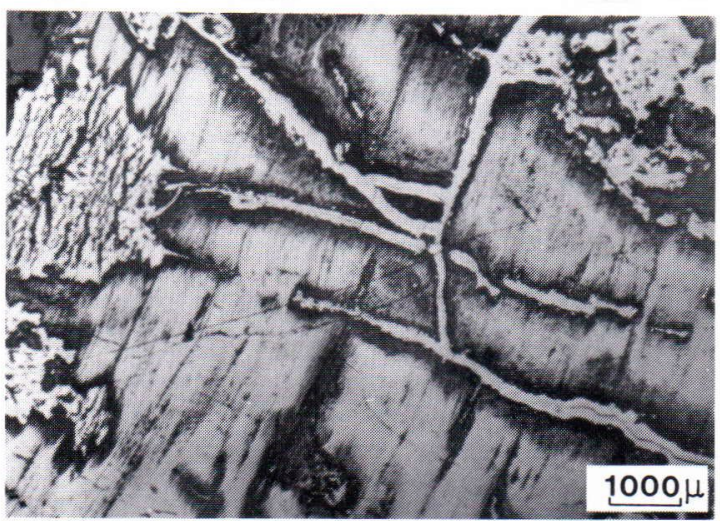

Fig. 12. Cellular texture of pyrrhotite replaced by Sb-bearing marcasite (lighter, relief) and »intermediate product» (light grey, poorly polished). 


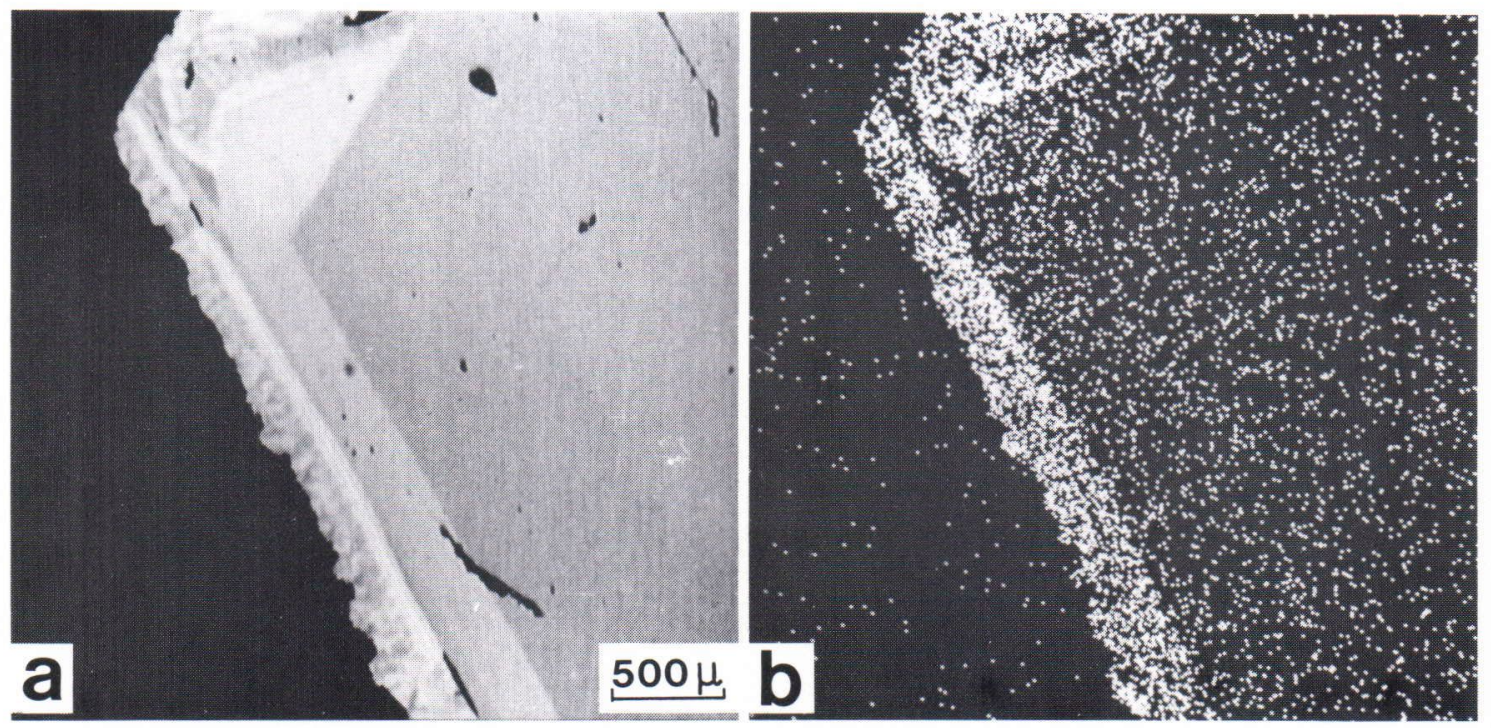

Fig. 13. Zonal crystal of Sb-bearing arsenopyrite. a) backscattered electron image; b) Sb L $\alpha_{1} \mathrm{X}$-rays image.

larger blebs (up to $10 \mathrm{~cm}$ in diameter) may also be countered. A specific feature of the native antimony is its arsenic content. Routine chemical analyses indicated that the content of As in a large hand specimen of antimony from the Törnävä deposit was $3.4 \%$ (Pääkkönen 1966) whereas in the Syrjämö deposit it was $3.26 \%$. Our investigations revealed that this mineral has a higher content of arsenic (up to $7-11 \%$ ). Arsenic is distributed uniformly in native antimony and its content is practically the same at the contact with the inclusions of arsenic minerals (arsenopyrite and löllingite). A lower As content $(0.3 \%)$ has been recorded only in native antimony whose grains contain inclusions of seinäjokite and $\mathrm{Sb}$-westerveldite (Mozgova et al. 1977).

\section{Arsenopyrite (FeAsS)}

Arsenopyrite is widespread and occurs as a diffused impregnation with grain sizes of up to $1 \mathrm{~mm}$. Individual crystals may be as long as $5 \mathrm{~mm}$. It usually forms distinct short-prism or elongated sharpedged crystals that are idiomorphic in respect of other minerals such as pyrrhotite, native antimony and gudmundite. Arsenopyrite inclusions are regularly present in native antimony, even in the small grains.

The arsenopyrite crystals in the ores of the Kalliosalo deposits exhibited some zonality, which is caused by variations in the antimony content and in the $\mathrm{Me} / \mathrm{S}$ ratio (Fig. 13, Table 3). The central and intermediate zones have different $\mathrm{Me} / \mathrm{S}$ ratios, whereas the external zone is composed of a brush of small prismatic crystals of antimony-bearing arsenopyrite that has grown on the surface of the main crystal. The rims of antimony-bearing arsenopyrite have also developed around gudmundite crystals (Fig. 14, Table 3). Arsenopyrite with a high content of Sb $(11 \%)$ has been found in the ores of the Urultan deposit in the northeastern USSR (Gamyanin et al. 1981). In the report by Fleischer (1955), it was shown that the $\mathrm{Sb}$ content in arsenopy- 
Table 3. Chemical composition of Sb-arsenopyrite from the Kalliosalo deposit, wt.\% (according to the microprobe data).

\begin{tabular}{lllllll}
\hline $\begin{array}{l}\text { Place of } \\
\text { analysis }\end{array}$ & $\mathrm{Fe}$ & $\mathrm{As}$ & $\mathrm{Sb}$ & $\mathrm{S}$ & Total & Formula \\
\hline
\end{tabular}

\begin{tabular}{lcccccc}
\hline \multicolumn{7}{c}{ Zonal crystal of Sb-arsenopyrite (see Fig. 13) } \\
Central part & 34.0 & 48.3 & 1.8 & 17.6 & 101.7 & $\mathrm{Fe}_{1.00}\left(\mathrm{As}_{1.06} \mathrm{Sb}_{0.03}\right)_{1.09} \mathrm{~S}_{0.91}$ \\
Intermediate part & 31.3 & 49.6 & 1.9 & 16.4 & 99.2 & $\mathrm{Fe}_{0.96}\left(\mathrm{As}_{1.14} \mathrm{Sb}_{0.03}\right)_{17} \mathrm{~S}_{0.88}$ \\
External zone & 33.5 & 37.3 & 12.0 & 18.6 & 101.4 & $\mathrm{Fe}_{1.01}\left(\mathrm{As}_{0.84} \mathrm{Sb}_{0.17}\right)_{1.01} \mathrm{~S}_{0.98}$ \\
& Margin & of Sb-arsenopyrite around gudmundite (see & $\mathrm{Fig}^{1}$ 14) \\
Inner zone & 33.8 & 38.9 & 6.1 & 18.0 & 96.8 & $\mathrm{Fe}_{1.05}\left(\mathrm{As}_{0.90} \mathrm{Sb}_{0.09}\right)_{0.99} \mathrm{~S}_{0.97}$ \\
External zone & 33.8 & 46.1 & 4.8 & 17.1 & 101.8 & $\mathrm{Fe}_{1.01}\left(\mathrm{As}_{1.03} \mathrm{Sb}_{0.07}\right)_{1.10} \mathrm{~S}_{0.89}$ \\
\hline
\end{tabular}

rite does not exceed $0.2 \%$. The data obtained by us demonstrate beyond doubt that rather extensive solid solution exists in nature between arsenopyrite and gudmundite (up to 17 at. $\% \mathrm{As})$.

\section{Löllingite $\left(\mathrm{FeAs}_{2}\right)$}

Löllingite occurs as small short-prismatic and elongated crystals up to $0.5 \mathrm{~mm}$ in size. The löllingite from the Seinäjoki ores contains nickel, sulphur and antimony (Table 4), which are the most typical elements of this mineral (Holmes 1947; Mikheev 1952). Löl-

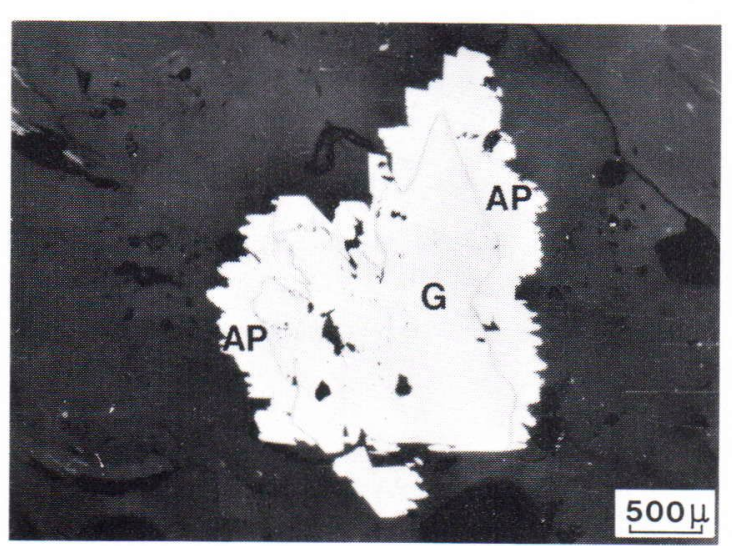

Fig. 14. Gudmundite (G) with rims of finely crystalline Sb-bearing arsenopyrite (AP). lingite from different deposits in the district exhibits marked compositional variations. The löllingite found at Sikakangas and replaced by arsenopyrite (Fig. 3) reveals the highest content of sulphur $(\sim 2 \%)$ and an absence of $\mathrm{Ni}$, whereas the mineral at Kalliosalo contains a minimal amount of sulphur ( $0.2 \%)$ but a maximal amount of nickel ( $~ 9 \%)$, much greater in fact than that encountered earlier (Holmes 1947; Busek 1963). The Kalliosalo löllingite contains antimony, too, which has not been found in any other deposit in the district.

\section{Gudmundite (FeSbS)}

Gudmundite was found in the form of small grains up to $1 \mathrm{~mm}$ in size, mainly rimming the pyrrhotite grains beyond the silicification zone. The chemical composition of the gudmundite is in good agreement with the theoretical one (Table 5). Note that, unlike its isostructural arsenic analogue, arsenopyrite (in which arsenic is largely replaced by antimony, as shown above), the gudmundite, even when intimately associated with arsenopyrite, lacks arsenic. This may suggest an incomplete solid solution between these minerals. 
Table 4. Chemical composition of löllingite, wt.\% (according to the microprobe data).

\begin{tabular}{lcccccrl}
\hline Deposit & Fe & Ni & As & Sb & S & Total & Formula \\
\hline Kalliosalo & 18.5 & 9.0 & 70.7 & 3.4 & 0.2 & 101.8 & $\left(\mathrm{Fe}_{0.68} \mathrm{Ni}_{0.32}\right)_{1.00}\left(\mathrm{As}_{1.93} \mathrm{Sb}_{0.06} \mathrm{~S}_{0.01}\right)_{2.00}$ \\
Routakallio & 25.2 & 2.4 & 73.5 & - & 0.6 & 101.7 & $\left(\mathrm{Fe}_{0.91} \mathrm{Ni}_{0.08}\right)_{0.99}\left(\mathrm{As}_{1.97} \mathrm{~S}_{0.04}\right)_{2.01}$ \\
Routakallio & 25.2 & 2.3 & 70.9 & - & 1.1 & 99.5 & $\left(\mathrm{Fe}_{0.92} \mathrm{Ni}_{0.08}\right)_{1.00}\left(\mathrm{As}_{1.93} \mathrm{~S}_{0.07}\right)_{2.00}$ \\
Sikakangas* & 27.2 & - & 71.2 & - & 2.0 & 101.4 & $\mathrm{Fe}_{0.97}\left(\mathrm{As}_{1.90} \mathrm{~S}_{0.13}\right)_{2.03}$ \\
\hline
\end{tabular}

* Replaced by arsenopyrite (see Fig. 3) with composition Fe - 33.6\%; As - 49.1\%; S - 17.4\%; total $-100.1 \%$, as indicated by microprobe data.

\section{Berthierite $\left(\mathrm{FeSb}_{2} \mathrm{~S}_{4}\right)$}

Berthierite is much less abundant than gudmundite, being encountered only as small isolated grains in the enclosing rocks. It is often intergrown with pyrrhotite and gudmundite and forms reaction rims around them. In the Kalliosalo ores, berthierite may occasionally be observed in association with and replacing native antimony. The largest grains of this mineral attain $1.6 \mathrm{~mm}$ in diameter. The composition of berthierite is consistent with the stoichiometric one (Table 5).

\section{Stibnite $\left(\mathrm{Sb}_{2} \mathrm{~S}_{3}\right)$}

Stibnite occurs as thin veinlets in the enclosing rocks (mainly parallel to their schistosity) and accumulations (up to $2 \mathrm{~mm}$ in diameter) of small acicular crystals. The mineral has very often grown along the boundaries of individual grains and aggregates of other sul- phides (pyrrhotite, gudmundite and berthierite) and native antimony. Stibnite veinlets have also been observed to cut these minerals. In composition stibnite is almost stoichiometric (Table 5).

\section{Sb-westerveldite [Fe(As, Sb)]}

Westerveldite occurs as small (up to 0.1 $\mathrm{mm}$ ) idiomorphic grains in native antimony (Mozgova et al. 1976 and 1977). Unlike westerveldite from other deposits, the mineral encountered in the Seinäjoki district is the only variety of antimony with the empirical formula $\mathrm{Fe}\left(\mathrm{As}_{0,94} \mathrm{Sb}_{0,05} \mathrm{~S}_{0,04}\right)_{1.03}$ (Table 6). The mineral studied is distinguished by the regular absence of $\mathrm{Co}$ and $\mathrm{Ni}$, although these elements have always been present in all westerveldites described earlier (Oen et al. 1971 and 1977; Sizgoric and Duesing 1973; Karup-Møller 1978). Sb-westerveldite has a comparatively high content of $\mathrm{S}(\sim 1 \%)$.

Table 5. Chemical composition of gudmundite, berthierite and stibnite, wt.\% (according to microprobe data).

\begin{tabular}{lllllrl}
\hline Mineral & Deposit & Fe & Sb & $\mathrm{S}$ & Total & Formula \\
\hline Gudmundite & Routakallio & 27.8 & 58.9 & 14.7 & 101.4 & $\mathrm{Fe}_{1.04} \mathrm{Sb}_{1.01} \mathrm{~S}_{0.95}$ \\
Gudmundite & Kalliosalo & 27.9 & 57.1 & 15.1 & 100.1 & $\mathrm{Fe}_{1.04} \mathrm{Sb}_{0.98} \mathrm{~S}_{0.98}$ \\
Berthierite & Kalliosalo & 12.6 & 58.0 & 30.3 & 100.9 & $\mathrm{Fe}_{0.96} \mathrm{Sb}_{2.02} \mathrm{~S}_{4.02}$ \\
Berthierite & Kalliosalo & 12.4 & 56.5 & 29.4 & 98.3 & $\mathrm{Fe}_{0.97} \mathrm{Sb}_{2.03} \mathrm{~S}_{4.00}$ \\
Stibnite & Routakallio & - & 74.0 & 28.5 & 102.5 & $\mathrm{Sb}_{2.00} \mathrm{~S}_{3.00}$ \\
Stibnite & Kalliosalo & - & 71.2 & 28.1 & 99.3 & $\mathrm{Sb}_{2.00} \mathrm{~S}_{3.00}$ \\
\hline
\end{tabular}


Table 6. Chemical composition of westerveldite from various deposits (wt.\%).

\begin{tabular}{|c|c|c|c|c|c|c|c|c|}
\hline Deposit & $\mathrm{Fe}$ & Co & $\mathrm{Ni}$ & $\mathrm{Cu}$ & As & $\mathrm{Sb}$ & $\mathrm{S}$ & Total \\
\hline $\begin{array}{l}\text { Seinäjoki } \\
\text { (Finland) }\end{array}$ & 42.4 & - & - & - & 53.7 & 4.7 & 1.0 & 101.8 \\
\hline $\begin{array}{l}\text { La Gallega } \\
\text { (Spain) }\end{array}$ & 28.1 & 0.7 & 13.4 & - & 55.7 & - & - & 98.9 \\
\hline$-"-$ & 26.6 & 0.65 & 17.4 & - & 55.55 & - & - & 100.2 \\
\hline $\begin{array}{l}\text { Igdlunguaq } \\
\text { (South } \\
\text { Greenland) }\end{array}$ & 35.9 & $<0.1$ & 6.6 & $<0.05$ & 57.2 & 0.15 & $<0.05$ & 99.85 \\
\hline$-»-$ & 36.5 & $<0.1$ & 5.65 & $<0.05$ & 57.2 & 0.15 & $<0.05$ & 99.5 \\
\hline $\begin{array}{l}\text { Illimaussaq } \\
\text { (South } \\
\text { Greenland) }\end{array}$ & 42.23 & 0.38 & 0.12 & - & 55.48 & - & 0.35 & 98.56 \\
\hline $\begin{array}{l}\text { Birchtree } \\
\text { (Canada) }\end{array}$ & 30.1 & 0.5 & 13.9 & - & 55.1 & 0.5 & & 100.1 \\
\hline
\end{tabular}

Seinäjokite $\mathrm{Fe}(\mathrm{S}, \mathrm{As})_{2}$

Seinäjokite was first discovered in the ores of the Routakallio deposit (Mozgova et al. 1976), where it was associated with Sb-westerveldite grains of native antimony. Seinäjokite has since been found in only one locality in Ilimaussaq (Karup-Møller, 1978). The mineral of the type occurrence has higher contents of $\mathrm{Co}, \mathrm{Ni}$ and AS (Table 7).

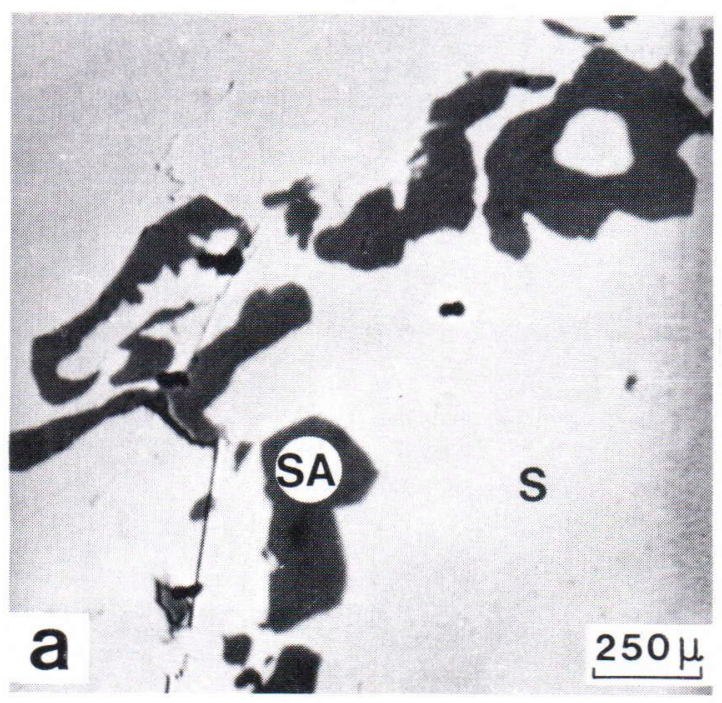

Stibarsen (AsSb)

Stibarsen (allemontite) forms rows of small (up to $0.06 \mathrm{~mm}$ ) crystals and grains of irregular shape in native antimony (Fig. 15). The chemical composition of this mineral corresponds precisely the stoichiometric one (Mozgova et al. 1976). The presence of stibarsen with native antimony may indicate that the complete solid solution between an-

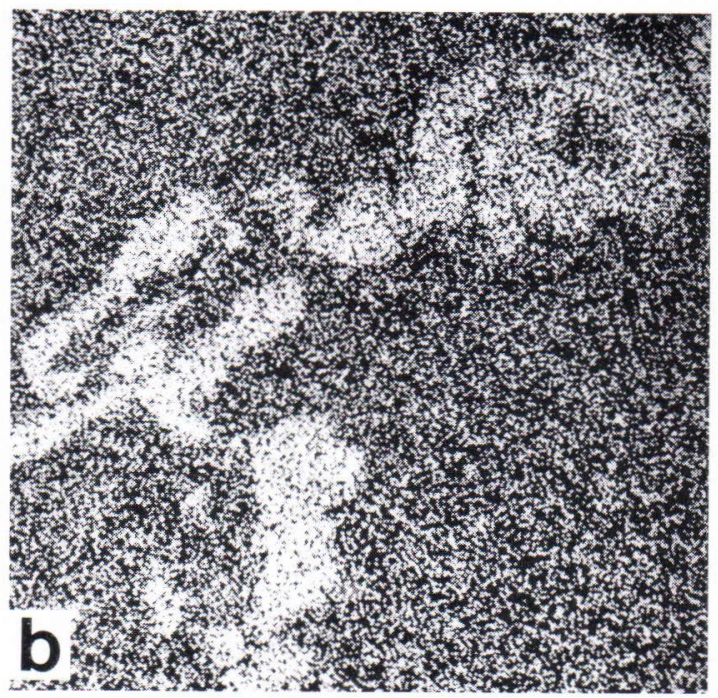

Fig. 15. Stibarsen (SA) aggregates in native antimony (S). a) backscattered electron image; b) As $K \alpha_{1}$ $\mathrm{X}$-ray image. 
Table 7. Chemical composition of seinäjokite from various deposits, wt.\% (according to data of microprobe analysis).

\begin{tabular}{|c|c|c|c|c|c|c|c|c|}
\hline No. Deposit & & & & & & & & \\
\hline $1 \begin{array}{l}\text { Routakallio } \\
\text { (Seinäjoki) }\end{array}$ & 15.4 & 0.6 & 4.0 & 6.9 & 73.5 & 1.2 & - & 101.6 \\
\hline $\begin{array}{ll}2 & \text { Ilimaussaq } \\
\text { (South } \\
\text { Greenland) }\end{array}$ & 17.41 & 0.33 & 0.28 & 1.75 & 81.45 & - & 0.08 & 101.3 \\
\hline
\end{tabular}

$1-\left(\mathrm{Fe}_{0.78} \mathrm{Ni}_{0.19} \mathrm{Co}_{0.03}\right)\left(\mathrm{Sb}_{1.71} \mathrm{As}_{0.26} \mathrm{Te}_{0.03}\right)$, average of the analysis of 6 grains (Mozgova et al., 1976, 1977) $2-\left(\mathrm{Fe}_{0.92} \mathrm{Co}_{0.02} \mathrm{Ni}_{0.01}\right)_{0.95}\left(\mathrm{Sb}_{1.97} \mathrm{As}_{0.07} \mathrm{~S}_{0.01}\right)_{1.05}$, average of the analysis of 10 grains (Karup-Møller, 1978).

timony and arsenic established at high temperatures (Hansen, Anderko, 1957) does not exist under natural conditions.

\section{Aurostibite $\left(\mathrm{AuSb}_{2}\right)$}

Aurostibite, like stibarsen, was initially discovered in the Seinäjoki ores by Mozgova et al. (1976). The mineral occurs as individual isometric inclusions (up to $0.15 \mathrm{~mm}$ in size) in native antimony (Fig. 16). The chemical composition of aurostibite is in full agreement with the theoretical one.

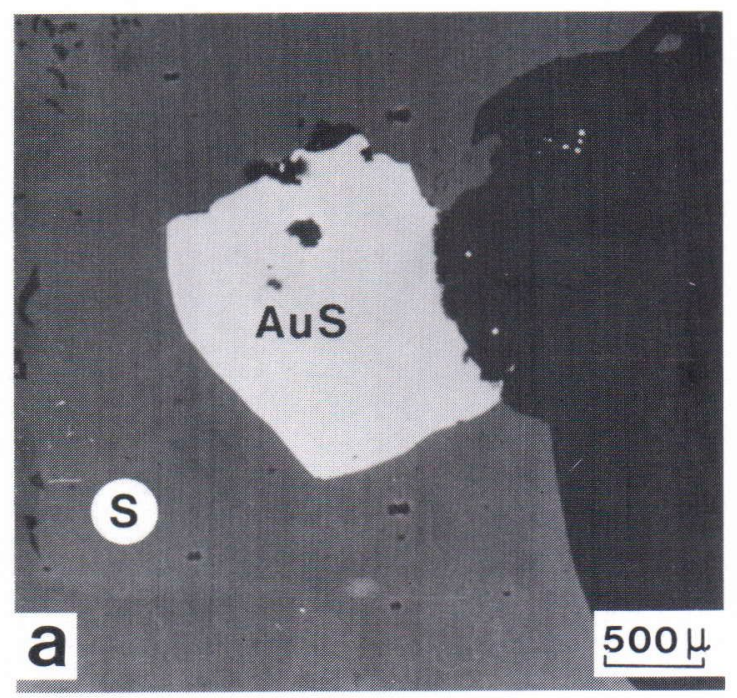

\section{Pääkkönenite $\left(\mathrm{Sb}_{2} A s S_{2}\right)$}

Pääkkönenite was first discovered in the ores of the Kalliosalo deposit and called after the late Veikko Pääkkönen, a Finnish geologist who made a great contribution to the study of the deposits in this district (Borodaev et al. 1981). Pääkkönenite occurs as laminated and rounded grains (up to $0.4 \mathrm{~mm}$ in size) intergrown with native antimony (Fig. 17), and with arsenopyrite and nickel-bearing löllingite. The grains of pääkkönenite are sometimes twinned. A recalculation of the

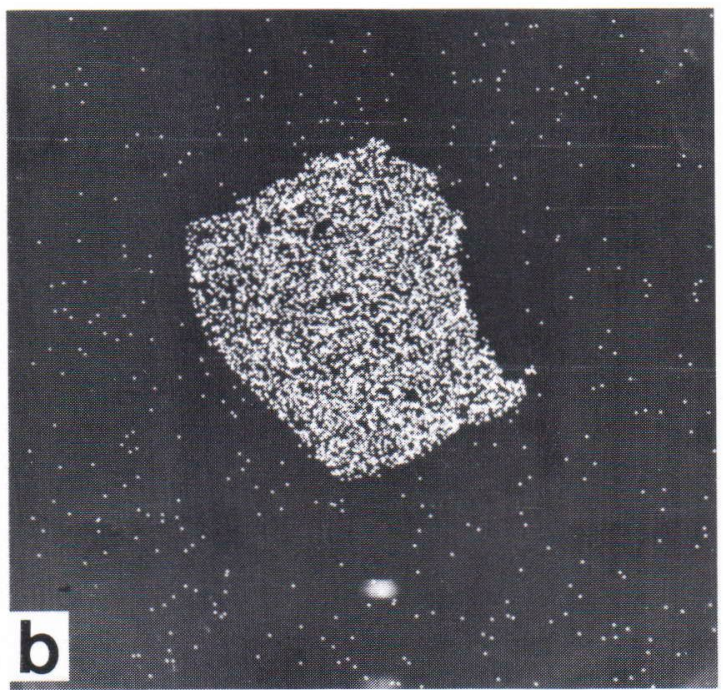

Fig. 16. Aurostibite (AuS) grain in native antimony (S) at the contact with quartz (black). a) backscattered electron image; b) $\mathrm{Au} \mathrm{M} \alpha$ X-ray image. 
Table 8. Chemical composition of pääkkönenite and artificial solid solutions, vt.\% (according to the data of microprobe analysis).

\begin{tabular}{|c|c|c|c|c|c|c|}
\hline \multicolumn{7}{|l|}{ Deposit } \\
\hline $\begin{array}{l}\text { Kalliosalo } \\
\text { (Seinäjoki) }\end{array}$ & 65.8 & 17.8 & - & 15.5 & 99.1 & $\mathrm{Sb}_{2.14} \mathrm{As}_{0.94} \mathrm{~S}_{1.92}$ \\
\hline$-»-$ & 65.3 & 18.9 & - & 15.1 & 99.3 & $\mathrm{Sb}_{2{ }_{13}} \mathrm{As}_{100} \mathrm{~S}_{186}$ \\
\hline$-»-$ & 65.9 & 18.7 & - & 15.4 & 100.0 & $\mathrm{Sb}_{2.13} \mathrm{As}_{0.98} \mathrm{~S}_{1.89}$ \\
\hline$-»-$ & 69.5 & 17.0 & - & 16.2 & 102.7 & $\mathrm{Sb}_{2,19} \mathrm{As}_{0.87} \mathrm{~S}_{1.94}$ \\
\hline$-»-$ & 68.0 & 17.9 & - & 15.5 & 101.4 & $\mathrm{Sb}_{2.18} \mathrm{As}_{0.93} \mathrm{~S}_{1.89}$ \\
\hline Average & 66.9 & 18.6 & - & 15.5 & 101.0 & $\mathrm{Sb}_{2.14} \mathrm{As}_{0.97} \mathrm{~S}_{1.89}$ \\
\hline $\begin{array}{l}\text { "New phase» } \\
\text { in equilibrium } \\
\text { with } \mathrm{Sb}_{2} \mathrm{~S}_{3} \text { and } \mathrm{Sb} \\
\text { (Craig et al.. 1974) }\end{array}$ & 65.9 & 17.4 & - & 16.7 & $100.0^{*}$ & $\mathrm{Sb}_{2.10} \mathrm{As}_{0.90} \mathrm{~S}_{2.00}$ \\
\hline $\begin{array}{l}\text { Phase X } \\
\text { (Luce et al., 1977) }\end{array}$ & 67.7 & 15.3 & 0.2 & 16.1 & 99.3 & $\mathrm{Sb}_{2.20} \mathrm{As}_{0.81} \mathrm{~S}_{1.99}$ \\
\hline - - - & 62.8 & 19.9 & 0.1 & 17.2 & 100.0 & $\mathrm{Sb}_{1.96} \mathrm{As}_{1.00} \mathrm{~S}_{2.04}$ \\
\hline $\begin{array}{l}\text { Theoretical } \\
\text { composition }\end{array}$ & 63.7 & 19.6 & - & 16.7 & 100.0 & $\mathrm{Sb}_{2} \mathrm{AsS}_{2}$ \\
\hline
\end{tabular}

* in wt.\% the analysis is recalculated from mol.\% given by the authors.

microprobe analysis (the average of five analyses, Table 8) gives us the following formula: $\mathrm{Sb}_{2.14} \mathrm{As}_{0.97} \mathrm{~S}_{1.89}$. Note that the composition of pääkkönenite exhibits insignificant variations and, like the artificial solid solution obtained in the system $\mathrm{Sb}-\mathrm{As}-\mathrm{S}$ by Craig et al. (1974) and Luce et al. (1977) in association with native antimony, it is characterized by an antimony content in excess of stoichiometric $\mathrm{Sb}_{2} \mathrm{AsS}_{2}$. The X-ray powder diffraction pattern of pääkkönenite is indexed to have a monoclinic unit cell with $\mathrm{a}_{0} 5.372 ; \mathrm{b}_{\text {o }}$
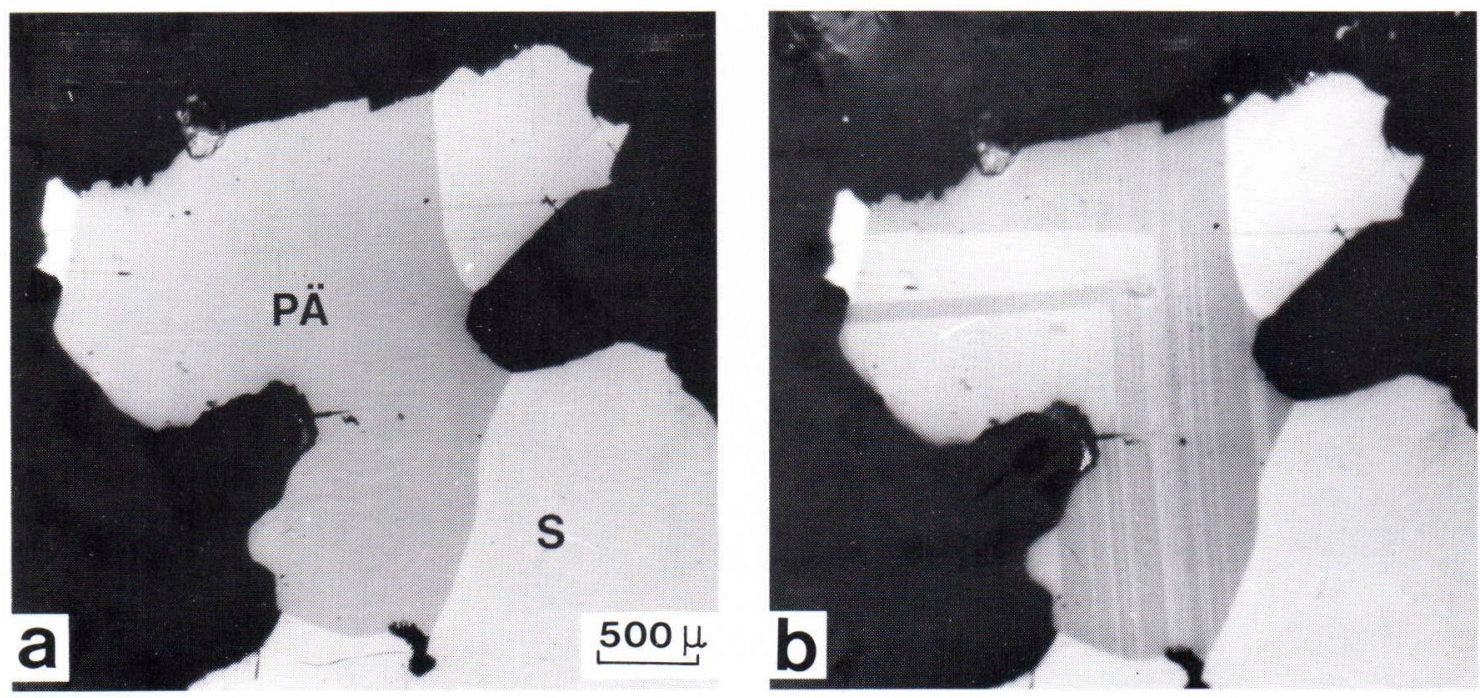

Fig. 17. Pääkkönenite (PÄ) intergrown with native antimony (S) in quartz. a) without analyser; b) with analyser. 
Table 9. Chemical composition of minerals $\mathrm{Y}$ and $\mathrm{Z}$, zinkenite, fahlore, chalcostibite and sphalerite, wt.\% (according to microprobe data).

\begin{tabular}{|c|c|c|c|c|c|c|c|c|c|c|c|}
\hline Deposit & Minerals & $\mathrm{Pb}$ & $\mathrm{Zn}$ & $\mathrm{Cu}$ & $\mathrm{Fe}$ & Mn & $\mathrm{Sb}$ & As & $\mathrm{S}$ & Total & Formulas \\
\hline Mineral Y & Kalliosalo & 10.0 & - & - & - & - & 59.7 & 15.4 & 14.8 & 99.9 & $\left(\mathrm{~Pb}_{0.99} \mathrm{Sb}_{10.07} \mathrm{As}_{4.03} \mathrm{~S}_{9.42}\right.$ \\
\hline Mineral Z & Kalliosalo & 17.0 & - & - & - & - & 56.9 & 11.9 & 15.0 & 101.4 & $\mathrm{~Pb}_{1.08} \mathrm{Sb}_{5.94} \mathrm{As}_{2.03} \mathrm{~S}_{5.96}$ \\
\hline Zinkenite & Kalliosalo & 34.8 & - & 0.9 & - & - & 45.8 & - & 22.1 & 103.6 & $\left(\mathrm{~Pb}_{0.94} \mathrm{Cu}_{0.08}\right)_{1.02} \mathrm{Sb}_{2.11} \mathrm{~S}_{3.85}$ \\
\hline Fahlore & Kalliosalo & - & - & 38.6 & 6.9 & - & 29.6 & - & 25.0 & 100.1 & $\mathrm{Cu}_{10.6} \mathrm{Fe}_{2.04} \mathrm{Sb}_{4.03} \mathrm{~S}_{12.88}$ \\
\hline$-»-$ & Kalliosalo & - & 2.0 & 38.8 & 5.2 & - & 30.3 & - & 25.9 & 102.2 & $\mathrm{Cu}_{9.88}\left(\mathrm{Fe}_{1.52} \mathrm{Zn}_{0.50}\right)_{2.02} \mathrm{Sb}_{4.03} \mathrm{~S}_{13.06}$ \\
\hline$-"-$ & Satamo & - & 1.7 & 39.1 & 5.5 & - & 31.3 & - & 25.0 & 102.2 & $\mathrm{Cu}_{10.05}\left(\mathrm{Fe}_{1.61} \mathrm{Zn}_{0.43}\right)_{0.04} \mathrm{Sb}_{4.19} \mathrm{~S}_{0.72}$ \\
\hline stibite & Kalliosalo & - & - & 25.9 & - & - & 48.1 & - & 25.3 & 99.3 & $\mathrm{Cu}_{1.03} \mathrm{Sb}_{0.99} \mathrm{~S}_{1.9}$ \\
\hline Sphalerite & Kalliosalo & - & 56.8 & - & 8.9 & 1.0 & - & - & 33.3 & 100.0 & $\left(\mathrm{Zn}_{0.83} \mathrm{Fe}_{0.15} \mathrm{Mn}_{0.02}\right) \mathrm{S}$ \\
\hline$-»-$ & Kalliosalo & - & 56.0 & - & 9.2 & 1.7 & - & - & 33.5 & 100.1 & $\left(\mathrm{Zn}_{0.81} \mathrm{Fe}_{0.16} \mathrm{Mn}_{0.03}\right) \mathrm{S}$ \\
\hline
\end{tabular}

$3.975 ; \mathrm{c}_{\mathrm{o}} 11.41 \AA ; \beta 89.71^{\circ}$, which is consistent with the lattice constants - $\mathrm{a}_{\mathrm{o}} 5.40, \mathrm{~b}_{\mathrm{o}} 3.98$; $\mathrm{c}_{\mathrm{o}} 11.40 \AA ; \beta 90^{\circ}$ suggested by Craig et al. (1974) for the synthetic phase $\mathrm{Sb}_{2} \mathrm{AsS}_{2}$.

\section{Mineral $Y\left(\mathrm{~Pb}_{2} \mathrm{Sb}_{20} A s_{8} \mathrm{~S}_{19}\right)$}

Mineral Y was also discovered for the first time in the ores of the Kalliosalo deposit. This mineral occurs as grains of irregular shape up to $0.1 \mathrm{~mm}$ in size in the contact with pääkkönenite. No compound of similar composition has ever been described either from nature or a synthetic system. A microprobe analysis of mineral $\mathrm{Y}$ has the recalculated idealized formula $\mathrm{Pb}_{2} \mathrm{Sb}_{20} \mathrm{As}_{8} \mathrm{~S}_{19}$ (Table 9).

\section{Mineral $\mathrm{Z}\left(\mathrm{PbSb}_{6} \mathrm{As} \mathrm{s}_{2} \mathrm{~S}_{6}\right)$}

Mineral $\mathrm{Z}$ is another phase that has not been encountered either in nature or as a synthetic variety. It was observed in association with zinkenite in the same polished section of ore from Kalliosalo deposit as mineral Y. It is about $0.1 \mathrm{~mm}$ in grain size. The results of the microprobe analysis of mineral $\mathrm{Z}$ are consistent with the idealized formula $\mathrm{PbSb}_{6} \mathrm{As}_{2} \mathrm{~S}_{6}$ (Table 9).

\section{Sphalerite (Zn, Fe, Mn)S}

Sphalerite occurs in pyrrhotite as small inclusions (up to $0.5 \mathrm{~mm}$ ) of irregular shape.

Microprobe analysis of sphalerite in the Kalliosalo deposit shows that it contains iron and manganese (Table 9).

\section{Chalcopyrite ( $\mathrm{CuFeS}$ )}

Chalcopyrite was found as exsolution bodies and veinlets in sphalerite and as small inclusions and veinlets in pyrrhotite.

\section{Pyrite $\left(\mathrm{FeS}_{2}\right)$}

According to Pääkkönen (1966), pyrite occurs in appreciable amounts in graphitic phyllite and in the zones of sericitic quartzite, but infrequently in association with antimony minerals. Pyrite and marcasite both replace pyrrhotite.

\section{Fahlore $C u_{10}(\mathrm{Fe}, \mathrm{Zn}) \mathrm{Sb}_{4} \mathrm{~S}_{13}$}

Fahlore has been found as a subordinate mineral as small irregular grains up to $0.5 \mathrm{~mm}$ in size in the ores of three deposits: Routakallio, Kalliosalo and Syrjämö. The mineral is usually intimately associated with pyrrho- 
tite, sphalerite and chalcopyrite. Fahlore from the Seinäjoki deposits is pure tetrahedrite with no arsenic (Table 9). A specific feature of this fahlore is the preponderance of iron over zinc. In some places, the pure iron-bearing variety, koppite, has also been noted as have variations in $\mathrm{Me} / \mathrm{S}$ content.

\section{Chalcostibite ( $\mathrm{CuSbS}$ )}

Chalcostibite has only been encountered in one polished section from the ores of the Kalliosalo deposit in an intimate in intergrowth with tetrahedrite and stibnite enclosed within a gudmundite crystal. The maximum size of the chalcostibite grains is $0.05 \mathrm{~mm}$. The composition of the mineral is close to the theoretical one (Table 9).

\section{Zinkenite $\left(\mathrm{Pb}_{1-n} \mathrm{Sb}_{4-n} \mathrm{~S}_{7}\right.$}

Zinkenite occurs as small grains (up to 0.4 $\mathrm{mm}$ in size) in the Kalliosalo deposit in close association with native antimony and mineral $Z$. The chemical composition of the zinkenite from the deposit (Table 9) is in the compositional range of the mineral established by Mozgova and Bortnikov (1980).

\section{Altaite (PbTe)}

Altaite forms graphic intergrowths with native antimony (Mozgova et al. 1976 and 1977). It has been found in association with other tellurides in the ores of the Routakallio deposit only. The tellurides are closely associated with seinäjokite, which contains only traces of Te.

The main feature of the ores studied is the extensive occurrence of native metal, and the presence of intermetallic compounds and sulphoarsenides (pääkkönenite, minerals Y and $\mathrm{Z}$ ) characterized by a sulphur content lower than that required by the valence of cations. Arsenic appears to play the role of anion in them, as it does in löllingite.

\section{Discussion on the physical and chemical conditions of formation of ores in the Seinäjoki district}

The fresh data given above on the mineralogy, paragenesis and chemical composition of minerals based on microprobe analyses and the results of experimental and thermodynamic studies on the systems $\mathrm{Fe}-\mathrm{As}-\mathrm{S}, \mathrm{Fe}-\mathrm{Sb}-\mathrm{S}$ and $\mathrm{As}-\mathrm{Sb}-\mathrm{S}$ contribute to a better understanding of the chemical and physical conditions of the antimony ore formation in the Seinäjoki district.

The temperature of formation of the quartzantimony mineralization can be estimated using:

a) solubility of sulphur in löllingite,

b) composition of arsenopyrite coexisting with löllingite and

c) the content of arsenic in native antimony associated with phase $\mathrm{X}\left(\mathrm{Sb}_{2} \mathrm{AsS}_{2}\right)-\mathrm{a}$ synthetic analogue of pääkkönenite.

The experimental data of Clark (1960) show that the solubility of sulphur in lollingite is $3.4 \mathrm{wt}-\%$ at $702^{\circ} \mathrm{C}$ and 3 wt. $\%$ at $650^{\circ} \mathrm{C}$. The position of the solvus curve, which determines the limit of sulphur solubility in löllingite in equilibrium with arsenopyrite, has not been determined accurately enough at lower temperatures. Nevertheless a rough extrapolation indicates that the increased content of sulphur in lollingite $(\sim 2 \%)$ from the Sikakangas deposit suggests that the temperature of formation was about $500^{\circ} \mathrm{C}$ ' Similar results are obtained when the temperature is determined using the experimental data of Kretschmar and Scott (1976) on the composition of arsenopyrite in association with löllingite and pyrrhotite. According to their data in this association, arsenopyrite with $36.6 \mathrm{wt}-\%$ As forms at approximately $500^{\circ} \mathrm{C}$. Lower temperatures are obtained when the content of As in the native antimony coexisting with pääkkönennite is used as a geothermometer. Luce and 
his co-authors (1977) have established that the minimal As content in antimony in association with the $\mathrm{Sb}_{2} \mathrm{AsS}_{2}$ phase, which is a synthetic analogue of pääkkönenite, is reduced from $14.8 \mathrm{wt} . \%$ at $500^{\circ} \mathrm{C}$ to $12.1 \mathrm{wt} \%$ at $425^{\circ} \mathrm{C}$. Consequently, the content of $11 \%$ As in native antimony must indicate a lower temperature of formation (below $425^{\circ} \mathrm{C}$ ) of the quartz-antimony association.

The authors believe that in this case, the most reliable results are obtained by estimating the upper thermal limit from the composition of the coexisting pääkkönenite and native antimony, since the relationship of these minerals observed in polished sections suggests that they were formed simultaneously. The other minerals pair, lollingite and arsenopyrite, however, is out of equilibrium owing to the distinct replacement of löllingite by arsenopyrite. We may therefore reasonably assume that the temperature of formation of the quartz-antimony mineral association was within $380^{\circ}-400^{\circ} \mathrm{C}$.

The sulphide-antimony association formed at temperatures lower than the quartzantimony assemblage. The upper thermal limit can be estimated using the temperature of gudmundite stability. According to Clark (1966), this temperature is $280^{\circ} \pm 10^{\circ} \mathrm{C}$, which is confirmed by the presence in the ores of monoclinic pyrrhotite, a mineral that is stable below $250^{\circ} \mathrm{C}$ (Scott \& Kissin 1974).

It is interesting to note the difference in the temperature of formation between the ores of the Seinäjoki district and of stibnite deposits, which are the principal source of antimony.

According to many investigators, the majority of the antimony minerals in the stibnite deposits formed at $130^{\circ}-180^{\circ} \mathrm{C}$. In the gold stibnite deposits only an early quartzpyrite-arsenopyrite association was deposited at higher temperatures $\left(280^{\circ}-380^{\circ} \mathrm{C}\right)$, whereas antimony ores (quartz-stibniteberthierite association) formed at $130^{\circ}-180^{\circ} \mathrm{C}$.
The fugacity of sulphur during the formation of the quartz-antimony association can be estimated from the data on the stability of the association of lollingite, the $\mathrm{FeSb}_{2}$ phase - the end member of the seinäjokite solid solution (Fe,Ni) ( $\mathrm{Sb}, \mathrm{As})_{2}$, and the FeAs phase - the end member of the westerveldite solid solution ( $\mathrm{Fe}, \mathrm{Ni}, \mathrm{Co}$ ) (As,Sb). According to Barton (1969 and 1971), the stability fields of the FeAs and $\mathrm{FeSb}_{2}$ phases at $400^{\circ} \mathrm{C}$ (a maximal temperature for the ore association in Seinäjoki) lies between $\mathrm{fs}_{2}=10^{-17}$ and $\mathrm{fs}_{2}=10^{-15} \mathrm{~atm}$. These values are much lower than the sulphur fugacity at which, according to Barton, the mineral associations of sulphides of the "main line» (Fig. 18) were deposited from hydrothermal solutions. The lower limit of sulphur fugacity during the formation of sulphide-antimony association is restricted by the stability of gudmundite. The minimal $\mathrm{fs}_{2}$ that allows the formation of this mineral at $280^{\circ} \mathrm{C}$ (thermal limit of its stability) must be below 10-20 atm (calculated from Barton's equation $\triangle \mathrm{g}=-79400+38.8 \mathrm{~T}$ for reaction $\left.2 \mathrm{Fe}+2 \mathrm{Sb}+\mathrm{S}_{2}=2 \mathrm{FeSbS}\right)$. The maximal sulphur fugacity during the deposition of these ores at the same temperature of $280^{\circ}$ can be estimated from the stability data on the association of löllingite with arsenopyrite and pyrrhotite whose stability range is restricted at this temperature by a value of sulphur fugacity of $10^{-15} \mathrm{~atm}$.

Thus it is possible that the sulphur fugacity varied during the formation of the Seinäjoki minerals from $10^{-17}$ to $10^{-15}$ atm at $400^{\circ} \mathrm{C}$ and from $10^{-15}$ to $10^{-20} \mathrm{~atm}$ at $280^{\circ} \mathrm{C}$. These values are much lower than those of $\mathrm{fS}_{2}$, according to Barton (op.cit.) are characteristic of the process of hydrothermal sulphide mineral formation at temperatures of $280^{\circ}-400^{\circ} \mathrm{C}$. It should be stressed that the antimony ores in the stibnite deposits crystallized at higher sulphur fugacity because the pyrite-stibniteberthierite association observed in these de- 


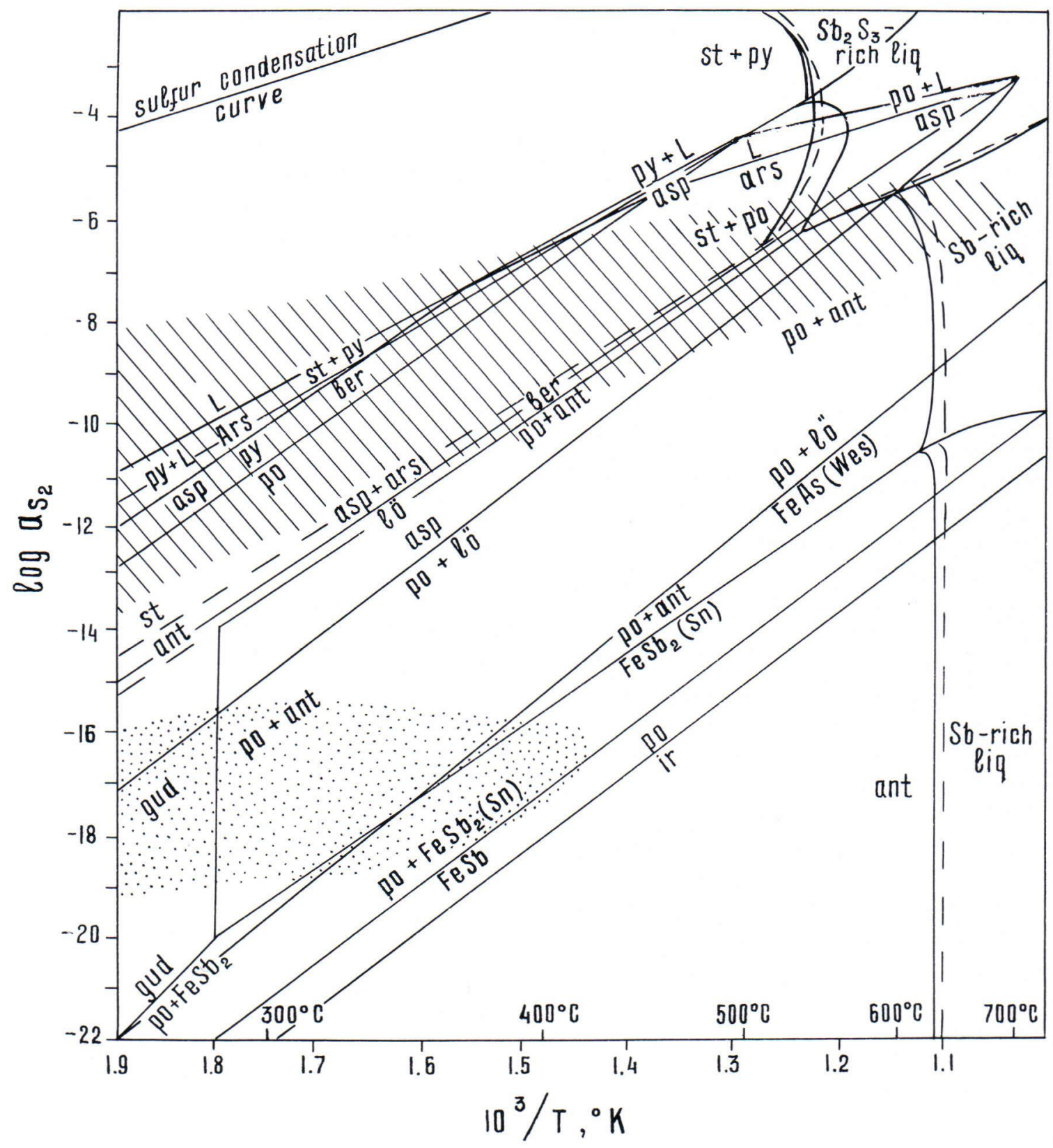

Fig. 18. Diagram of sulphur activity - temperature for sulphurization reactions in systems $\mathrm{Fe}-\mathrm{As}-\mathrm{S}$ and $\mathrm{Fe}-\mathrm{Sb}-\mathrm{S}$, from data provided by Barton $(1969,1971)$. Reactions gud $=$ po + ant and gud $=$ po + $\mathrm{FeSb}_{2}$ are shown schematically. Hatched part is the region of sulphur temperatures and activities characteristic of sulphide ore formation - "main line", according to Barton (1970). The dotted part is the region of sulphur temperatures and activities during the formation of the deposits of the Seinäjoki district. Abbreviations: ant - antimony, ars - arsenic, asp - arsenopyrite, ber - berthierite, gud - gudmundite, ir - iron, $\Lambda$ - liquid, po - pyrrhotite, lö - löllingite, py - pyrite, st - stibnite, sn - seinäjokite, wes westerveldite. The crossings of equilibrium lines in the system $\mathrm{Fe}-\mathrm{Sb}-\mathrm{As}-\mathrm{S}$ are not nonvariable points. 
posits is stable at $\mathrm{fs}_{2}$ of about $10^{-11}-10^{-12}$ atm at $130^{\circ}-180^{\circ} \mathrm{C}$.

The present study helps us to understand the specific features of the behaviour of the main ore-forming elements: antimony, arsenic and sulphur during the process of mineral formation and suggests a model of metasomatic formation for the ores in the deposits of the Seinäjoki district. A complete extraction of pyrrhotite from the enclosing rocks of intensely altered metamorphic series indicates undersaturation of the hydrothermal solutions in iron and sulphur, which resulted in the dissolving of pyrrhotite and the remobilization of $\mathrm{Fe}$ and $\mathrm{S}$ (Korzhinskii 1955). The progressive saturation of the intergranular solutions with iron gave rise to the formation of the next metasomatic zone made up of the minerals of sulphide antimony association due to the interaction of antimony-bearing solutions with pyrrhotite. This suggests inert behaviour of iron in this zone. The formation in the same zone of a number of reaction minerals of a similar qualitative composition but differing in the quantitative ratio of their constituent components (for example, löllingite, Sb-westerveldite, gudmundite-berthierite) is a result of a change in the activity of the components, that is, of antimony, arsenic and sulphur, in the mineral-forming solution together with

\section{References}

Barton P. B., 1969. Thermochemical study of the system $\mathrm{Fe}-\mathrm{As}-\mathrm{S}$. Geochim. Cosmochim. Acta $33,841-857$.

Barton P. B., 1970. Sulfide petrology. Miner. Soc. Amer. Spec. Pap. 61, 187-196.

Barton P. B., 1971. The $\mathrm{Fe}-\mathrm{Sb}-\mathrm{S}$ system. Econ. Geol. 66, 121-132.

Borodaev Yu. S., Mozgova N. N., Ozerova N. A., Bortnikov N. S., Oivanen P., \& Yletyinen V., 1981. Pääkkönenite $-\mathrm{Sb}_{2} \mathrm{AsS}_{2}-$ a new mineral from ore district Seinäjoki in Finland. Zapiski the existence of temperature gradient (Korshinskii 1955). However, that the content of the components of the mineral solid solutions (native antimony, arsenopyrite-gudmundite solid solution, tetrahedrite, seinäjokite, löllingite) fluctuate and that zoning in these minerals can be accounted for by the non-equilibrium conditions of ore deposition. The paragenetic sequence observed in the mineral formation reflects the process of sulphurization as the concentration of sulphur in the minerals formed increases progressively. Such a sequence in mineral-formation can be attributed either to enhanced sulphur concentration due, for example, to a dissolution of sulphides (pyrrhotite) in the rear zone of the column or to a lowering of temperature.

The data obtained therefore suggest that mineral formation in the deposits of the Seinäjoki district occurred under specific conditions. The minerals were formed at temperatures relatively high for antimony deposition, and at sulphur fugacity extremely low for hydrothermal processes. These two factors resulted in the formation of the unique antimony ores made up of virtually monomineral native antimony and unusual associations of native metals, intermetallic compounds and minerals incompletely saturated with sulphur.

Vsesojusnogo Mineralog. Obschestva 110, 4 (in Russian).

Busek P. R., 1963. The $\mathrm{Fe}-\mathrm{Ni}-\mathrm{As}$ system at $800^{\circ} \mathrm{C}$. Carnegie Inst. Washington Year Book 62, $200-210$.

Clark A. H., 1965. Heating experiments on gudmundite. Miner. Mag. 35, 1123-1125.

Clark L. A., 1960. The Fe-As-S system: phase relations and applications, Pt. I and II. Econ. Geol. 55, 1345-1381, 1631-1652.

Craig J. R., Skinner B. Y., Francis C. A., Luce F. D., 
Makovicky M., 1974. Phase relations in the As-Sb-S system (abstr.). Amer. Geophys. Union Trans. 55, 483.

Fleischer H., 1955. Minor elements in some sulfide minerals. Econ. Geol. 50th Anniv. vol. II, 970-1024.

Gamyarin G. N., Nekrasov I. Ya., Leskova N. V.\& Ryabova E. G., 1981. Antimonian variety of arsenopyrite - a first occurrence. Miner. Journ. (Kiev) 3, 87-96.

Hansen M. \& Anderko K., 1958. Constitution of binary alloys. Mc Graw-Hill, New York, 1305.

Holms R. Y., 1974. Higher mineral arsenides of cobalt, nickel and iron. Bull. Geol. Soc. Amer. 58, 299-392.

Karup-Moller S., 1978. The ore minerals of the Ilimaussaq intrusion: their mode of occurrence and their conditions of formation. Gronland Geol. Unders. bull. 127, 1-5.

Karup-Moller S. \& Makovicky E., 1977. Westerveldite from Ilimaussaq alkaline intrusion in South Greenland. Mineralogy, crystallography, mineral associations and alteration product. Neues Jb. Miner. Abh. 130, 208-242.

Korzhinskii.D. S., 1955. Otscherk metasomaticheskich processov. In the book: »Osnovnije problemi w utschenii o magmatogennih rudnich mestorogzdenijah», Moscow, 335-456 (in Russian).

Krebschmar U. \& Scott S. D., 1976. Phase relations involving arsenopyrite in the system $\mathrm{Fe}-\mathrm{As}-\mathrm{S}$ and their application. Can. Miner. 14, 364-386.

Lepp H., 1957. The synthetic and probable geologic significance of melnikovite. Econ. Geol. 52, 528.

Luce F. D., Tuttle C. L. \& Skinner B. Y., 1977. Studies of sulfosalts of copper: V. Phases and phase relations in the system $\mathrm{Cu}-\mathrm{Sb}-\mathrm{As}-\mathrm{S}$ between $350^{\circ}$ and $500^{\circ} \mathrm{C}$. Econ. Geol. 72, 271-289.

Minerali (spravochnik). 1960 Moscow, 312 p. (in Russian).

Miheev W. I., 1952. X-ray study of the natural threeand di-arsenides. "Kristallographia» 2, 75-112, Moscow-Leningrad (in Russian).

Mozgova N. N., Borodaev Yu. S., Ozerova N. A., Pääkkönen V., et al., 1976. Seinäjokit $\left(\mathrm{Fe}_{0.8} \mathrm{Ni}_{0,2}\right)$ $\left(\mathrm{Sb}_{1.7} \mathrm{As}_{0.32}\right)$ i sarmjanistii westerveldit $\mathrm{Fe}$ -
$\left(\mathrm{As}_{0.95} \mathrm{Sb}_{0.05}\right)$ iz Seinäjoki (Finlandija). Zapiski Vsesojuznogo Mineralog. Obschestva. 6, 617630 (in Russian).

Mozgova N. N., Borodaev Yu. S., Ozerova N. A. \& $P a ̈ a ̈ k k o ̈ n e n ~ V ., 1977$. New minerals of the group of iron antimonides and arsenides from Seinäjoki deposit, Finland. Bull. Geol. Soc. Finland 49, 47-52.

Mozgova N. N. \& Bortnikov N. S., 1980. On nonstoichiometry of acicular lead sulphoantimonides. In Int. Geol. Gongr. XXVI session, reports of Soviet geologists. Geochemistry, Mineralogy. Nauka, Moscow, 126-138.

Novgorodova M.I., 1980. Novaja gruppa prirodnich tverdih rastvorov i intermetallidov. Int. Geol. Congr. XXVI session, reports of Soviet geologists. Geochemistry, mineralogy. Nauka, Moscow, 108-113.

Oen I. S., Burke E. A. J., Kieft C. \& Westerhof A. B., 1971. Ni-arsenides, Ni-rich loellingite and (Fe, $\mathrm{Co}$-rich gersdorffite in $\mathrm{Cr}-\mathrm{Ni}$-ores from $\mathrm{Ma}$ laya province, Spain, Neues Jb. Miner., Abh. 115, 123-139.

Oen I. S., Burke E. A. J. \& Kieft C., 1977. Westerveldite from Igdlunguaq, Ilimaussaq alkaline massif, South Greenland. Min. Mag. 41, 77-83.

Pääkkönen V., 1966. On the geology and mineralogy of the occurrence of native antimony at Seinäjoki, Finland. Bull. Comm. Geol. Finland 225. $70 \mathrm{p}$.

Ramdohr P., 1975. Die Erzmineralien und ihre Verwachsungen. 4. Auflage, Akademie-Verlag, Berlin, 648-651.

Scott S. D. \& Kissin S. A., 1973. Sphalerite composition in the $\mathrm{Zn}-\mathrm{Fe}-\mathrm{S}$ system below $300^{\circ} \mathrm{C}$. Econ. Geol. 68, 475-479.

Simonen A., 1980. The Precambrian of Finland. Geol. Surv. Finland. Bull. 304, 58 p.

Sizgoric M. B. \& Duesing C. M., 1973. Westerveldite, a Canadian occurrence. Can. Miner. 12, 2.

Springer G. D., 1967. Die berechnung von Korrekturen für die quantitative ElectronenstrahlMicroanalyse. Fortschr. Miner. 45, 103-118.

Manuscript received, May 19, 1982 